\title{
From Political Borders to Social Boundaries
}

\author{
BY \\ ROMAN URBANOWICZ
}

\begin{abstract}
Olga Sasunkevich
Informal Trade, Gender and the Border experience: from political Borders to Social Boundaries, Ashgate: Farnham, Burlington, 2015. 199 p.

ISBN 978-1-4724-6221-3
\end{abstract}

The book 'Informal Trade, Gender and the Border experience: from political Borders to Social Boundaries', written by Olga Sasunkevich, addresses the issue of relations between political border regimes and social boundaries, instantiated on the example of female practices of semi-legal petty trans-border trade at the Belarusian-Lithuanian border. It was originally written as a dissertation during the author's Ph.D. track at Greifswald University, Germany, and was defended with summa cum laude.

The book consists of an introduction, six substantial chapters and a conclusion. In the introduction, the author describes the empirical materials she uses. They include not only interviews with women from the town of Ašmiany, but also thoroughly analysed statistical sources and newspapers' publications, as well as some modicum of ethnographic data. She also presents the theoretical foundations of her research, presenting three conceptual questions that she deploys meticulously in the book. These questions are the following: how does a political border perform its functions; what are the relations between spatial and social mobility; how does crossing a border work as moment that reproduces social divisions through the mechanisms of the border's selective openness (10-11).

Chapters 1-5 examine the subject of how the the history of the BelarusianLithuanian political border regime affected practices of the female shuttle trade in the Belarusian border town of Ašmiany. Particularly, the first chapter describes the historical, social and cultural context of the author's research. Chapter 2 begins with an examination of the unrestricted mobility between the two Soviet republics in the late Soviet period (the author considers the 70 s and $80 \mathrm{~s}$ ). In chapter 3 , the 
author continues with an account of the emergence of the two independent states in the immediate post-Soviet period. The differences in their economic policies predetermined the blossoming of a semi-legal shuttle trade as a way of coping with the economic decline that followed post-socialist transformations. Sasunkevich points out this trade was to a significant extent predicated on the experience of the ethnically framed practices of transnational mobility and smuggling to and from Poland established in Soviet times.

In chapters 4 and 5, Sasunkevich analyses the 'maturation of the border', that is, the gradual development of the restrictive border regime and its influence on the shuttle trade. Basically, the history of border is divided into three parts: the introduction of mutual visa regimes in 1994, further restrictions implemented in 2003, and its transformation into the 'mature border' of the European Union that operates the rules of the Schengen acquis. The author demonstrates, using De Certeau's categories of tactics and strategies (seen as different types of rational action, spontaneous and opportunity-related on the one hand and thoroughly pre-calculated on the other; de Certeau 1988) ${ }^{1}$, how changes in the regime of the 'selective openness' of the border affected different modes of participation in petty trade of different groups of Ašmiany women.

Particularly impressive is the sixth chapter of the book, in which Sasunkevich puts informal petty trade within the broader context of gendered economic conditions and survival strategies. The author presents the existing situation as an outcome of what she calls 'forced emancipation', when self-reliance and selfsustainability do not bring moral satisfaction, because independence stems from unfavourable conditions rather than from deliberate aspiration to personal autonomy (p. 151). The author also pinpoints specific female resources for the shuttle trade, such as use of particular social networks and culturally appropriate patterns of behaviour (such as begging border authorities for forgiveness; as opposed to those associated with masculinity), that influence the female character of the petty shuttle trade and enable particular forms of female agency and solidarity. This last chapter thus provides a rich and intelligent depiction of gender regimes (conceived as system of relations of power that shape notions of masculinity and femininity within particular institutions) of post-socialist transformations.

However, since the more thoughtful appreciations of this profound work can be found elsewhere, ${ }^{2}$ I would like to use the opportunity to outline some other possible

\footnotetext{
However, an 'infrastructural' dimension of the relations of power is somewhat missed from the author's use of de Certeau's concepts. The latter particularly emphasises that strategies are used by those capable of distinguishing their 'own' (i.e., controlled) areas from the environment, whereas 'the space of a tactic is the space of the other. Thus it must play on and with a terrain imposed on it and organized by the law of a foreign power. < ..> In short, a tactic is an art of the weak' (de Certau 1988, 37).

2 (Gradskova 2015); for quite a peculiar account from the vantage point of the economics see Laki (2016).
} 
directions of speculation over the presented materials, those that remained scarcely mentioned, namely, relations between the state and the people, and the ethics involved in those relations. It seems to me, that the unpronounced presence of these topics in the book is no less valuable than the author's adroit conceptualisations.

Naturally, the whole context for the book - the existence and operation of the state-border - is possible due to the state working on its limits, conceiving the state as an array of apparatuses ensuring legitimation of power (Abrams 2006). In this context, it seems productive to delve deeper into the relations between the state and its supposed obedient subjects. For instance, how does the state reproduce its symbolic power, using both direct and oblique techniques of governance? How are state policies apprehended and utilised by the affected population? The author does indeed analyse precisely these matters throughout the book. ${ }^{3}$ Nonetheless, further theorising in terms of, for example, concurrent evasion of state power (Scott 2009) and utilisation of (and longing for) its structures (Jansen 2014; cf. p. 128-129 of the book in question) could enable a more holistic and insightful perspective on trans-border petty trade practices. Considering that the emergence of the border does not only mean the building of a barrier, but also the fact that the people under discussion became subjects of new states, more direct enquiry with regard to attitudes concerning perceived structures of opportunities provided by the state ${ }^{4}$ might also enrich the analysis.

Furthermore, ethical considerations ${ }^{5}$ would also emerge as a natural continuation of the inquiry in the aforementioned matters. Those ethics, I suggest, should be seen as the result of internalisation of particular ideologies, imposed or suggested by the state or other influential actors of both local and global scale. With regard to this book, I would select the following: ethics of labour, mobility and ethnicity.

Idioms of morality and ethics with respect to petty trade are scattered throughout the text. The author mentions 'a moral barrier which distinguishes trade from non-trade [emphasis added]' (p. 129), 'A peculiar lack of hesitation to be engaged into cross-border smuggling' ( $\mathrm{p}$. 132), the factors which 'make this activity highly legitimized and acceptable' as well as both scholarship and informants' account of 'normalisation' of informal economics (p. 133), 'moral hesitations or consideration of trade as a non prestigious practice' (p. 136) and downright disdain towards 'speculators' expressed by some locals as well as

3 In the conclusion, Sasunkevich overtly states that the border practices in question can be seen as 'circumventing experience that brings economic advantages and provides people with moral satisfaction' (p. 169).

4 Cf. with 'normalcy of the state' in Greenberg 2011, which is estimated with regard to the opportunities for mobility and positive agentive action, provided by the state to its subjects.

5 Ethics here are comprehended as particular sets of internalised attitudes, expressed (since we are dealing mostly with interviews) prescriptive codes, and guidelines engendering a particular perception of what is right and what is wrong (moral and immoral, honourable and demeaning etc.). 
external observers (p. 162). In this regard, additional scrutiny of several subjects can be of use. Particularly, what occupations and types of employment are endowed with what 'moral value' and doer's assumed 'dignity'? What ethics of goal-setting and evaluation of different modes of agency (cf. 'entrepreneurial governmentality' in Yurchak 2002) are relevant in the field? How such notions are related to state-imposed sets of values (cf. p. 76) and their produced vernacular collectivities (see Dunn 1998; Mrozowicki and Van Hootegem 2008; Thelen 2005)? How are relations between being successful and being 'modernised' (cf. with 'global production of desire' by Trouillot 2001) apprehended?

Concomitantly, the closely adjoining matter of the ethics of mobility itself comes to mind when the author mentions her informant, who 'condemned those people who saw shopping or trade as the primary aims of their visits to Vilnius' (125), thus invoking the subject of ethics of consumption and leisure. ${ }^{6}$ She also mentions a Catholic priest, who fretted over parishioners who ostensibly use visas obtained for purposes of religious activity to instead go shopping. In this instance, further exploration of institutions other than the state, claiming and inculcating particular ethics of mobility, can be suggested.

The other ethics, taciturnly appearing in the text, are what I would call ethics of ethnicity, that occur when the author examines the case of the Polish Charter (Karta Polaka) - a document, issued by the Polish Ministry of Foreign Affaires, that proves one's 'belonging to the Polish nation', as it formulated officially, and facilitate receiving of a Polish Schengen visa - as a means of mobility. ${ }^{7}$ She mentions, that besides the function of signifying one's cultural belonging to 'the Polish nation' (as the official formulation claims), pragmatic motivations of facilitating the obtaining of Schengen visas can underpin one's decision to receive the document (p. 127).

What is particularly interesting is that Sasunkevich also gives examples of negative assessments - expressed both by the state and by representatives of pro-democratic and pro-nationalistic civil society — of such 'pragmatic' attitudes (p. 128). In this regard, it could be useful to see the mobility resource, provided by the Polish Charter, as a means ${ }^{8}$ in competition between different states for symbolic sovereignty over the particular group of people - those

6 And, in a sense, dim repercussions of what can be called 'cultivation of ethical self', in terms of formation of particular aesthetical preferences and habits that are supposed to be ethically laden (cf. Hirschkind 2006).

7 Although this one, probably, is the least of all three related to the topic of the book. However, the field of anthropology of ethnicity is particularly dear to the author of this review, which is supposed to excuse this review.

8 Even if not utilised by those affected in an expected vein. However, the author stresses in various places that the selective openness of the border can be apprehended as a factor that distributes resources of mobility unequally, thus allowing particular people to operate profitably on this disparity. 
eligible for receiving the Polish Charter (cf. Wilson and Donnan 1998). Notions of ethnic belonging as a moral practice (and, in a sense, of ethnicity as a moral performance) in this case are invoked by interested parties in order to counteract this 'material argument' in the symbolic competition. Further deliberations on these matters, in theory, guide towards a fertile soil for studying the social life of 'ethnic' identifications that surpass their conventional (i.e. imposed by state ideologies and the logic of vernacular banal nationalism) perception in terms of 'solemn' patriotic feelings and moral obligations. Some thoughts, in a way resembling this idea, are presented in the conclusion of the book, where the author describes how the unequal access to the cross-border mobility can be distributed along ethnic boundaries (p. 168).

However, this deferential outline of possible interpretative extensions is by no means intended to claim that the work lacks proper conceptualisation, but solely to emphasise its inconspicuous meanings and implications. The book of Olga Sasunkevich presents a sophisticated and nuanced account of female petty trade at the Belarusian-Lithuanian border. It provides a vivid and deep description of everyday experiences of 'small people' facing arbitrarily devised state policies of bordering, a power they can neither fathom nor affect, who hence implement multiple tactics and strategies in the search for agencies and resources to cope with inauspicious circumstances. The dearth of such bottom-up approaches towards post-socialist modernity is experienced particularly acutely in Belarusian intellectual discourses, and thus it is a pity indeed that this book has yet to receive the wider attention and critical engagement it deserves. ${ }^{9}$

\section{References}

Abrams, Philip, 2006. 'Notes on the Difficulty of Studying the State', in Aradhana Sharma and Akhil Gupta eds., The Anthropology of the State: A Reader, 112-30. Malden: Blackwell.

Certeau, Michel de, 1988. The Practice of Everyday Life. Berkeley: California University Press.

Dunn, Elizabeth, 1998. 'Slick Salesmen and Simple People: Negotiated Capitalism in a Privatized Polish Firm', in Michael Burawoy and Katherine Verdery eds., Uncertain Transition: Ethnographies of Change in the Post-Socialist World, 125-50. Lanham: R. and Littlefield.

\footnotetext{
9 Except rather formal reviews from within Western academia.
} 
Gradskova, Yulia, 2015. 'Female Shuttle Trade Between Belarus and Lithuania. Dissertation Review.' Baltic Worlds. 2015. Available at: <http://balticworlds.com/ female-shuttle-trade-between-belarus-and-lithuania-dissertation-review/ $>$.

Greenberg, Jessica, 2011. 'On the Road to Normal: Negotiating Agency and State Sovereignty in Postsocialist Serbia', American Anthropologist, 113 (1): 88-100.

Hirschkind, Charles, 2006. The Ethical Soundscape: Cassette Sermons and Islamic Counter-Publics in Egypt. New York: Columbia University Press.

Jansen, Stef, 2014. 'Hope For/Against the State: Gridding in a Besieged Sarajevo Suburb', -Ethnos, 79 (2): 238-60.

Laki, Balasz, 2016. 'Review on: Olga Sasunkevich (2015), Informal Trade, Gender and the Border Experience', Central and Eastern European Migration Review, 2016. Available at: <http://www.ceemr.uw.edu.pl/vol-6-no-1-2017/bookreviews/olga-sasunkevich-2015-informal-trade-gender-and-border-experience>.

Mrozowicki, Adam, and Van Hootegem, Geert, 2008. 'Unionism and Workers' Strategies in Capitalist Transformation: The Polish Case Reconsidered', European Journal of Industrial Relations, 14 (2): 197-216.

Scott, James, C., 2009. The Art of Not Being Governed: An Anarchist History of Upland Southeast Asia, New Haven \& London: Yale University Press.

Thelen, Tatjana, 2005. 'The Loss of Trust: Changing Social Relations in the Workplace in Eastern Germany’, Max Planck Institute for Social Anthropology Working Papers, 78.

Trouillot, Michel-Rolph, 2001. 'The Anthropology of the State in the Age of Globalization: Close Encounters of the Deceptive Kind', Current Anthropology, 42 (1): 125-138.

Wilson, Thomas M., and Hastings, Donnan. 1998. 'Nation, State and Identity at International Borders', in Thomas M. Wilson and Hastings Donnan, Border Identities: Nation and State at International Frontiers, 1-30. Cambridge: Cambridge University Press.

Yurchak, Alexei, 2002. 'Entrepreneurial Governmentality in Post-Socialist Russia: A Cultural Investigation of Business Practices', in Victoria Bonell and Thomas Gold, The New Entrepreneurs of Europe and Asia, 278-324. Armonk, N. Y.: M.E. Sharpe. 